\title{
Land Use Conversion and Soil Properties in a Lowland Tropical Landscape of Papua New Guinea
}

\author{
Nangu George ${ }^{1}$, Rajashekhar Rao Bangadi Killur ${ }^{2}$, David Lopez Cornelio ${ }^{1 *}$
}

${ }^{1}$ Department of Forestry, PNG University of Technology, PMB, Lae 411, Papua New Guinea

${ }^{2}$ Department of Agriculture, PNG University of Technology, PMB, Lae 411, Papua New Guinea

Received Oktober 26, 2012/Accepted February 25, 2013

\begin{abstract}
Land use conversion affects natural soil processes and can potentially decrease soils productivity. A representative area was selected to study the effects of land use conversion in Unitech Campus, Southeastern lowlands of Papua New Guinea (PNG). Area selected for the study was once covered by tropical rainforest and has been subjected to various land use types over time. Representative soil samples were collected under 4 main land use types (secondary forest, plantation forest, grassland, and agricultural garden) at 2 depths (0-0.15 m and 0.15-0.30 m) with 3 replicates per land use. Soil bulk density, water infiltration rate, and cumulative water infiltration values were significantly greater $(p<0.05)$ under grasslands than under secondary and plantation forests. Among soil chemical properties, extractable potassium content and $\mathrm{pH}$ showed significant differences $(p<0.05)$ among the land uses, $p H$ values increased upon conversion of forested lands to grassland or agricultural gardens. Conversion of secondary forests into grasslands or agricultural gardens leads to depletion of Bray's phosphorus and extractable potassium. Tree-based land uses were optimum due to better nutrient cycling conditions and lower bulk density compared to grassland and agricultural garden despite the low $\mathrm{pH}$ conditions and lower water infiltration.
\end{abstract}

Keywords: effects of land use, soil physical and chemical properties, soil fertility loss, land productivity decline

*Correspondence author, email: davlzo26@gmail.com,phone: +675-47-34661,fax:+675-47-34669

\section{Introduction}

In the last decades extensive land use changes occurred in tropical countries through conversion of natural forest lands into subsistence farming, cash cropping, mining, and logging to meet growing needs for the increasing population (Hartemink et al. 2008). They accelerate land degradation and decrease land productivity (FAO 1999), making vital the establishment of sustainable patterns of land use (Houghton 1994).

Papua New Guinea (PNG) has a land area of 46.3 million ha of which $65 \%$ are forests; their area decreased from 38 to 33 million ha between $1972-2002$ at a rate of 362,000 ha year $^{-1}$ (Hanson et al. 2001; Shearman et al. 2009). Customary land ownership dominates on $97 \%$ of the land, only $3 \%$ of it is under state ownership. In the last few decades an increase of rural population by more than $40 \%$ boosted an increase in cropped areas by $10 \%$ (McAlpine et al. 2001). Major factors of deforestation in PNG are commercial logging ( $48 \%$ of net forest cover change) and land clearing (46\%) for subsistence agriculture (Shearman et al. 2008). Deforestation studies shows considerable changes in soil physical and chemical properties some of which can influence the productivity potential of forest soils. During land conversion extent and type of vegetation cover changes, and such changes can influence soil erosion process. Studies in the highlands of
PNG found that soil erosion could range from $10 \mathrm{tha}^{-1} \mathrm{year}^{-1}$ in slopes of less than $10^{\circ}$ with vegetation cover up to $70 \%$ to $50 \mathrm{t} \mathrm{ha}^{-1}$ year $^{-1}$ from soils without vegetation cover with slopes up to $30^{\circ}$ (Humphreys \& Wayi 1990). Land cover changes disrupt soil nutrient cycles. Previous studies in PNG have shown that under agricultural land use up to 5-times greater amounts of phosphorous nutrient is lost due to higher runoff and soil loss compared to forests or grasslands (Lopez \& Rao 2011). Cropping destabilizes soil structure and increases soil bulk density (BD), the concomitant decrease on soil pore spaces affect water infiltration rate (IR) and accelerates runoff and erosion.

Conversion of forest lands to cropping areas in oxisols of Brazil resulted in $28 \%$ of organic matter loss after 5 years of conventional cropping in the top soil layer (Neufeldt et al. 2002). A similar soil type in Peru lost 30.23 and $25 \mathrm{~kg} \mathrm{ha}^{-1}$ of nitrogen $(\mathrm{N})$, phosphorus $(\mathrm{P})$, and potassium $(\mathrm{K})$ through leaching and volatilization resulting in productivity decline of $1.5 \mathrm{t} \mathrm{ha}^{-1}$ in 3 years (Jordan 1985). Conversion of Imperata spp. grassland to farms (legume fields, agroforestry, and cassava fields) in mollisols of Indonesia, increased the soil porosity by $7 \%$, soil organic carbon (SOC) by $6 \%$, and total nitrogen by $18 \%$ (Handayani et al. 2012).

The balance between input and output of soil nutrients determines their availability. Major sources of input are soil 
mineral weathering, atmospheric deposition, and biological fixation and litter decomposition; of output are lost through leaching, erosion, denitrification, and plant uptake (Binkley 1986). Changes in land use pattern can affect the inputs and output of nutrients in soil system thus can influence available nutrients and soil physical quality. Soil quality in turn determines the ability of the soil to sustainable support plant growth. This study aims to investigate the relationship between land use practices and their effects on soil properties. The findings of this study will support and direct future programs of land rehabilitation, soil conservation, agricultural intensification, and reforestation by providing scientific evidence of the effects of land uses on soil fertility. It is hypothesized that specific land use conversions have significant effects on soil fertility in a lowland tropical landscape of PNG.

\section{Methods \\ Study site and land use types The study site was located at Taraka Campus, 5 kilometers from Lae city in Morobe Province, PNG. Soil at the study site was classified as entisols with different vegetation covers, at an average altitude of $63 \mathrm{~m}$ asl, and with average rainfall of 2,900 $\mathrm{mm}$. The climate in the lowland is hot and humid with temperature ranges between 24 to $30{ }^{\circ} \mathrm{C}$ and average of $27{ }^{\circ} \mathrm{C}$ (Breget 2008). The study site was originally a lowland tropical rainforest, in the last decades gradually converted to plantation forest (Pinus caribaea), secondary forest (Terminalia complanata, Pterocarpus indicus, Homalium foetitium, Antiaris toxicaria), patches of grasslands (Imperata cylindrica), and agricultural gardens (Arachis hypogaea, Musa sp., Saccharum officinarum, Colocasia esculenta, and Ipomoea batatas).}

Sampling and data collection Soil samples were collected from the 3 subplots of $1.0 \mathrm{~m}^{2}$ selected to represent each land use system in the June, 2012. Within each subplot 12-15 soil cores were collected at random and bulked. Thus, 3 replicates for each land use were collected for both $0-0.15 \mathrm{~m}$ and $0.15-0.30 \mathrm{~m}$ depths, totaling 24 soil samples for laboratory analysis. Water infiltration field tests were conducted by double ring infiltrometer method in the subplots chosen for sample collection, which consists of 2 galvanized rings of 0.30 and $0.80 \mathrm{~m}$ diameter with $0.30 \mathrm{~m}$ height. Infiltration rate was recorded every 5 minutes (ASTM 2003). In each subplot infiltration measurement was taken for 30 minutes. Soil bulk density (BD) was estimated by core method after oven-drying the soil cores collected with a core cutter of $0.05 \mathrm{~m}$ height (Gradwell \& Birrell 1979).

Soil analysis Soil samples were air-dried, ground and sieved with a $2 \mathrm{~mm}$ sieve prior to chemical analysis. Samples were analyzed at the soils laboratory of National Agricultural Research Institute (NARI) in Port Moresby. Total nitrogen content was determined by Kjeldahl digestion method (Blakemore et al. 1987), extractable phosphorus by Bray-1 method (Bray \& Kurtz 1945), exchangeable potassium by neutral normal ammonium acetate extraction method (Blakemore et al. 1987), soil organic carbon by WalkleyBlack method (Ogle et al. 2003), and soil pH were recorded by dipping a glass electrode in a 1:2.5 (w/v) soil-water suspension (Blakemore et al. 1987). Soil texture was determined by the hydrometer method, in which soil particles were first treated with $30 \%$ hydrogen peroxide to destroy organic matter. Later, the sample was dispersed with sodium metaphosphate, agitated with a mechanical stirrer and density of soil particles in the dispersed fluid was measured with a hydrometer (Gee \& Bauder 1986).

Statistical analysis Soil test results for bulk density, textural analysis, $\mathrm{pH}$, organic carbon content, Bray's phosphorous content, and extractable potassium contents were analyzed by Factorial ANOVA model with Statistix 8.0 at $95 \%$ confidence level. Land use types and soil depths were considered as 2 factors and linear model procedure was used to determine the $F$-test significance. Whenever, F test was significant then means were separated by Least Significant Differences (LSD) test. Data on water infiltration test was subjected to simple one-way ANOVA in Completely Randomized Design. Pearson's multivariate correlation analysis was also carried out to ascertain relationship between and among different soil variants.

\section{Results and Discussion}

There were highly significant differences $(p<0.001)$ in $\mathrm{BD}$ among different land use types and varied significantly $(p<0.05)$ with soil depth (Table 1$)$. Lower BD values were recorded under secondary forest $\left(0.56 \mathrm{mg} \mathrm{m}^{-3}\right)$, closely followed by agricultural gardens $\left(0.61 \mathrm{mg} \mathrm{cm}^{-3}\right)$, plantation forest $\left(1.09 \mathrm{mg} \mathrm{m}^{-3}\right)$, and highest value under grassland (1.31 $\left.\mathrm{mg} \mathrm{m}^{-3}\right)$. Similar trend was noticed in subsurface soil $(0.15-$ $0.30 \mathrm{~m})$. BD values were greater in subsurface soil $(0.15-$ $0.30 \mathrm{~m})$ than surface soils $(0-0.15 \mathrm{~m})$ irrespective of the land use types. Our results were comparable to those reported by several researchers (Batjes \& Dijkshoon 1999; Yao et al. 2010). Loss of organic matter by the conversion of natural forests into pasture/grasslands and cultivated land generally causes higher BD values (Kizilkaya \& Dengiz 2010). Besides, anthropogenic activities such as tillage and traffic can also result in loss of biogenic soil structure and therefore increase the $\mathrm{BD}$ values. Larger $\mathrm{BD}$ values were an indication of slight compaction under grasslands. Studies have shown that forest land conversion to pasture/grasslands could result in soil compaction (Deuchars et al. 1999).

Soil particle size distribution did not show any significant $(p>0.05)$ differences between the land use types particularly regarding sand and clay content (Table 1 ). However, significant $(p<0.05)$ differences were found between different land uses regarding silt content. Lowest silt content (14\%) was recorded in agricultural gardens, while, greatest value $(29.7 \%)$ was noticed under grasslands. Generally, lands subjected to agricultural activities are prone for soil loss due to surface soil erosion during runoff events. Over the years of agricultural use of the soils under repeated tillage activity, soil particles could detach from soil aggregates and finer soil fractions could be easily transported away. Greater runoff and soil loss have been reported in agricultural land use compared to forest and grasslands under the lowland climatic conditions of PNG (Cornelio \& Killur 2011).

Land use types varied significantly $(p<0.05)$ regarding 
Table 1 Soil bulk density and textural composition in two soil depths $(0-0.15 \mathrm{~m}$ and $0.15-0.30 \mathrm{~m})$ under different land use types. Factorial ANOVA results for the interactions between land use types and soil depths were non-significant for all parameters

\begin{tabular}{|c|c|c|c|c|c|}
\hline \multirow[t]{2}{*}{ Soil depth (m) } & \multirow[t]{2}{*}{ Land use type } & \multirow[t]{2}{*}{ Bulk density $\left(\mathrm{mg} \mathrm{m}^{-3}\right)$} & \multicolumn{3}{|c|}{ Particle size distributi on } \\
\hline & & & Sand $(\%)$ & Silt (\%) & Clay $(\%)$ \\
\hline \multirow[t]{4}{*}{$0-0.15$} & Secondary forest & $0.56 \mathrm{c}$ & 59.7 & $18.7 \mathrm{abc}$ & 21.7 \\
\hline & Plantation forest & $1.09 \mathrm{~b}$ & 52.0 & $22.7 \mathrm{abc}$ & 25.3 \\
\hline & Grassland & $1.31 \mathrm{a}$ & 51.3 & $29.7 \mathrm{a}$ & 19.0 \\
\hline & Agriculture & $0.61 \mathrm{c}$ & 61.7 & $14.0 \mathrm{bc}$ & 24.3 \\
\hline \multirow[t]{4}{*}{$0.15-0.30$} & Secondary forest & $0.66 \mathrm{c}$ & 65.7 & $14.7 \mathrm{bc}$ & 19.7 \\
\hline & Plant ation forest & $1.17 \mathrm{~b}$ & 57.3 & $18.3 \mathrm{abc}$ & 24.3 \\
\hline & Grassland & $1.37 \mathrm{a}$ & 56.3 & $26.7 \mathrm{ab}$ & 17.0 \\
\hline & Agriculture & $0.68 \mathrm{c}$ & 73.7 & $11.0 \mathrm{c}$ & 15.2 \\
\hline$F$ test significance & & \multicolumn{4}{|c|}{$p$ value } \\
\hline Land use type & & 0.0008 & 0.0966 & 0.0145 & 0.2479 \\
\hline Soil depth & & 0.0398 & 0.1095 & 0.2485 & 0.1550 \\
\hline
\end{tabular}

Columns with same letter indicate that means are not significantly different from each other.

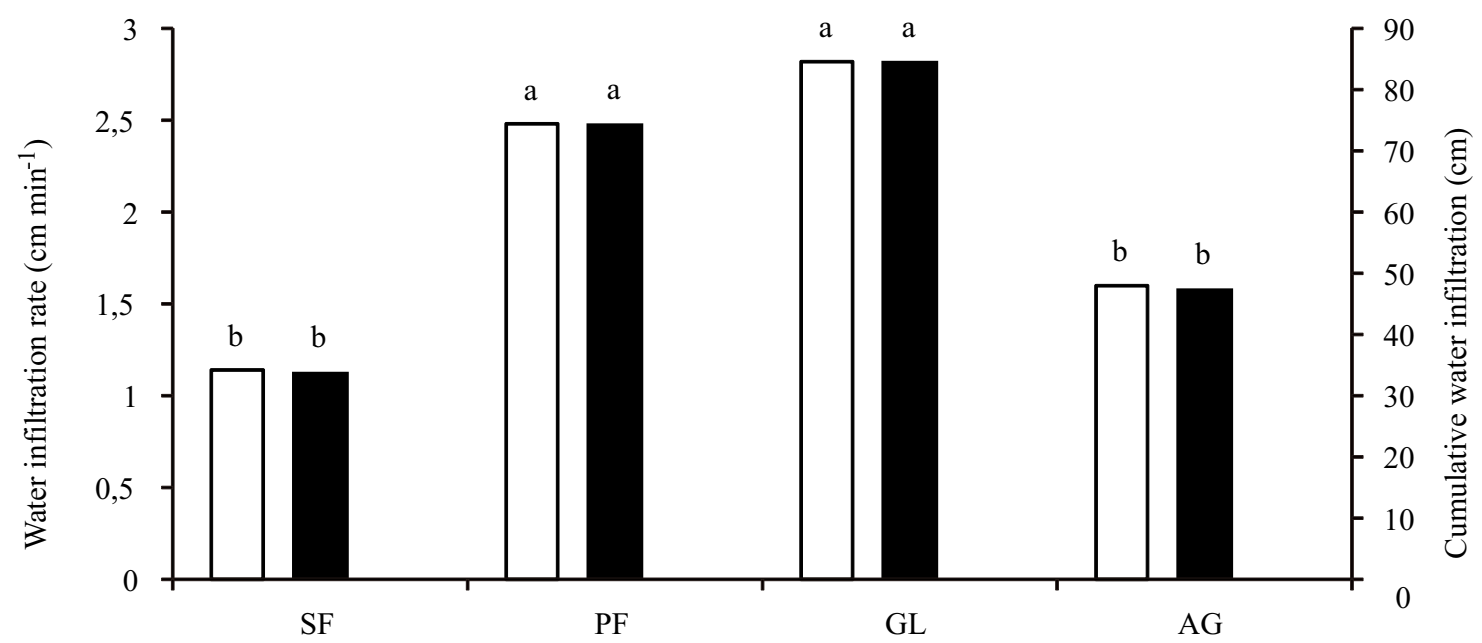

Figure 1 Water infiltration rate and cumulative water infiltration in the surface soil of different land use types. SF secondary forest; PF: plantation forest; GL: grassland; AG: agricultural garden. Bars with same letter are not significantly different from each other. Infiltration rate $\left(\mathrm{cm} \mathrm{min}^{-1}\right)(\boldsymbol{\square})$, cummulative infiltration $(\mathrm{cm})(\square)$.

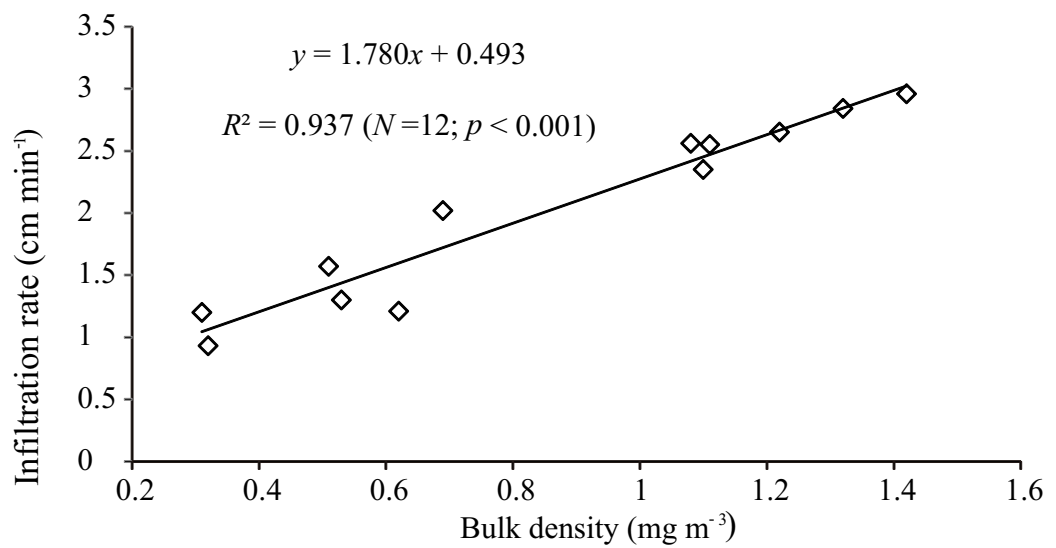

Figure 2 Relationship between water infiltration rate and soil bulk density in the surface soil of different land use types. 
Table 2 Fertility parameters in 2 soil depths $(0-0.15 \mathrm{~m}$ and $0.15-0.30 \mathrm{~m})$ under different land use types. Factorial ANOVA results for the interactions between land use types and soil depths were non-significant for all parameters

\begin{tabular}{|c|c|c|c|c|c|c|}
\hline Soil depth (m) & Land use types & $\mathrm{pH}$ & $\begin{array}{l}\text { Soil organic } \\
\text { carbon }\left(\mathrm{g} \mathrm{kg}^{-1}\right)\end{array}$ & $\begin{array}{l}\text { Total nitrogen } \\
\left(\mathrm{g} \mathrm{kg}^{-1}\right)\end{array}$ & $\begin{array}{l}\text { Bray's } \\
\text { phosphorous }\end{array}$ & $\begin{array}{l}\text { Extractable } \\
\text { potassium }\end{array}$ \\
\hline \multirow[t]{4}{*}{$0-0.15$} & Secondary forest & $5.23 \mathrm{bc}$ & $24.9 \mathrm{a}$ & $1.6 \mathrm{a}$ & 11.8 & $0.94 \mathrm{a}$ \\
\hline & Plantation forest & $5.10 \mathrm{c}$ & $25.4 \mathrm{a}$ & $1.8 \mathrm{a}$ & 19.9 & $0.62 \mathrm{ab}$ \\
\hline & Grassland & $5.43 \mathrm{ab}$ & $21.1 b$ & $1.5 \mathrm{ab}$ & 6.7 & $0.47 \mathrm{ab}$ \\
\hline & Agriculture & $5.20 \mathrm{bc}$ & $28.9 \mathrm{a}$ & $1.7 \mathrm{a}$ & 14.6 & $0.45 \mathrm{ab}$ \\
\hline \multirow[t]{4}{*}{$0.15-0.30$} & Secondary forest & $5.33 \mathrm{bc}$ & $11.4 \mathrm{c}$ & $0.8 \mathrm{c}$ & 11.9 & $0.95 \mathrm{a}$ \\
\hline & Plantation forest & $5.34 \mathrm{abc}$ & $6.2 \mathrm{c}$ & $0.7 \mathrm{c}$ & 8.8 & $0.47 \mathrm{ab}$ \\
\hline & Grassland & $5.60 \mathrm{a}$ & $10.5 \mathrm{c}$ & $0.8 \mathrm{c}$ & 8.4 & $0.32 b$ \\
\hline & Agriculture & $5.27 \mathrm{bc}$ & $13.4 \mathrm{c}$ & $0.9 \mathrm{bc}$ & 10.7 & $0.25 \mathrm{~b}$ \\
\hline$F$ test significance & & & & $p$ value & & \\
\hline Land use type & & 0.0323 & 0.3034 & 0.9681 & 0.2053 & 0.0272 \\
\hline Soil depth & & 0.0656 & 0.0000 & 0.0001 & 0.1715 & 0.3848 \\
\hline
\end{tabular}

Columns with same letter indicate that means are not significantly different from each other.

Table 3 Pearson's correlation coefficients $(r)$ between various soil properties under different land use systems

\begin{tabular}{|c|c|c|c|c|c|c|c|c|}
\hline & $\mathrm{BD}$ & Sand \% & Silt \% & Clay \% & $\mathrm{pH}$ & $\mathrm{SOC}$ & $\mathrm{TN}$ & Bray's -P \\
\hline Sand $\%$ & -0.289 & & & & & & & \\
\hline Silt \% & 0.403 & $-0.891 * *$ & & & & & & \\
\hline Clay \% & -0.031 & $-0.688 * *$ & 0.283 & & & & & \\
\hline $\mathrm{pH}$ & 0.388 & -0.095 & 0.324 & -0.315 & & & & \\
\hline SOC & -0.278 & 0.001 & -0.125 & 0.199 & $-0.438 *$ & & & \\
\hline $\mathrm{TN}$ & -0.080 & -0.246 & 0.089 & 0.378 & $-0.422 *$ & $0.909 * *$ & & \\
\hline Bray's-P & -0.301 & 0.120 & -0.187 & 0.046 & $-0.457^{*}$ & $0.427^{*}$ & 0.255 & \\
\hline Exctr K & $-0.484 *$ & 0.079 & -0.059 & -0.073 & -0.129 & 0.172 & 0.035 & $0.521^{*}$ \\
\hline
\end{tabular}

BD: bulk density; SOC: soil organic carbon; TN: total nitrogen; Extr K: extractable potassium

* indicates that correlation is significant at $p<0.05$

$* *$ indicates that correlation is significant at $p<0.01$

water infiltration rates (Figure 1). Water infiltration rate was greatest $\left(2.82 \mathrm{~cm} \mathrm{~min}^{-1}\right)$ in grassland, followed by plantation forest $\left(2.48 \mathrm{~cm} \mathrm{~min}^{-1}\right)$, agricultural garden $(1.60$ $\left.\mathrm{cm} \mathrm{min}^{-1}\right)$, and least in secondary forest $\left(1.14 \mathrm{~cm} \mathrm{~min}^{-1}\right)$. Akin to this trend, cumulative water infiltration also significantly differed between land uses. BD values of top soils across different land use types were positively and significantly correlated $(r=0.968 ; p<0.01)$ to the infiltration rate (Figure 2). Infiltration rates were expected to decrease with the increase in compaction or increasing BD values. On the contrary, in our study we noticed that infiltration rates increased with the increase in $\mathrm{BD}$ values. One of the reasons could be that the BD values for most of the samples covering 3 land use types were very low (except for the grasslands). Besides, according to Lichner et al. (1994) grass roots can affect infiltration rates in topsoil directly by inducing the preferred flow through macro-pores or indirectly by their influence on soil structure.

Among the various chemical properties studied, land use significantly $(p<0.05)$ influenced the soil reaction $(\mathrm{pH})$ and extractable K content (Table 2). Surface soils in all land use types were strongly acidic, plantation forest showing the lowest $\mathrm{pH}$ (5.23). Maximum soil $\mathrm{pH}$ was recorded under grass lands (5.43). With the increase in soil depth, soil $\mathrm{pH}$ values increased in all four land use types. Soil organic carbon and total nitrogen contents significantly $(p<0.05)$ decreased with the soil depth. Higher $\mathrm{pH}$ in grasslands could be due to the better recycling and conservation of basic cations in these soils. Spatial comparisons of areas historically dominated by trees and grasses indicate that soil $\mathrm{pH}$ and base saturation tend to be lower under forests with similar parent materials and climates. Under forest stand, soils are prone to acidification and leaching of basic cations and hence a lower $\mathrm{pH}$ value (Ugolini et al. 1988). However, afforestation studies on grasslands have revealed that in many instances cation cycling and redistribution by trees, rather than cation leaching by organic acids or enhanced carbonic acid production in the soil, is the dominant mechanism of acidification (Jobbagy \& Jackson 2003). Commonly followed practices of slash and burn can add ash material thus increasing the soil $\mathrm{pH}$ under agricultural gardens and grassland soils (Sanchez 1976), which affects the availability of nutrients. Highest soil organic carbon (SOC) content $\left(28.9 \mathrm{~g} \mathrm{~kg}^{-1}\right)$ was recorded in agricultural soil, while lowest SOC content was noticed under grasslands $\left(21.1 \mathrm{~g} \mathrm{~kg}^{-1}\right)$. The SOC concentration in a soil depends on balance between primary productivity, amount of biomass recycled to soil (Bulluck et al. 2002) and the rate of 
biologically-mediated organic matter decomposition processes. Soil conditions such as $\mathrm{pH}$ can influence decomposition rates of SOC. Studies conducted (van Noordwijk et al. 1997; Schroth et al. 2002) elsewhere found a decrease in organic carbon with time when forested areas were shifted to agriculture or secondary forest or mixed forests. However, our results contradicted such observations. Agricultural gardens in PNG are fallowed after few production cycles rather than continuously cultivated (Hanson et al. 2001) thus providing opportunity for SOC build up. Another important reason could be that farmers in PNG collect and use leaf composts to fertilize their agricultural gardens. Such practices could supply additional biomass and organic carbon in the agricultural soil.

Soil chemical properties showed degradation trend particularly regarding phosphorous and potassium availability. Land uses with standing trees (secondary forest and plantation forest) had a positive effect on phosphorous and potassium fertility. Bray's phosphorous $\left(6.7-19.9 \mathrm{mg} \mathrm{kg}^{-1}\right)$ and extractable potassium (0.25-0.94 c mol kg ${ }^{-1}$ ) were within medium range of availability (London 1991). Bray-P contents were lower in grasslands and agricultural gardens. Consistent with our findings, inorganic $P$ contents of the soils have been reported to be greater under forest systems compared to grasslands of New Zealand mainly due to nutrient pumping and stratification in the top layers (Belton et al. 1996). Efficiency of nutrient extraction and stratification increases with increase in biodiversity or in mixed stand of grassland vegetation (Oelmann et al. 2011). Nevertheless, in our study lower Bray's- P concentrations $\left(8.8 \mathrm{mg} \mathrm{kg}^{-1}\right)$ was noticed in plantation forest than that of secondary forest $\left(11.9 \mathrm{mg} \mathrm{kg} \mathrm{kg}^{-1}\right)$ and possibly such explanation could hold good for forest systems.

Extractable $\mathrm{K}$ content was 2-fold lower in surface soils due to the conversion of secondary forests to agricultural garden. K content was almost four-fold lower in subsurface soils $(0.15-0.30 \mathrm{~m})$ due to agricultural activities. Empirical critical limit of soil in Indonesia was $0.20 \mathrm{c} \mathrm{mo} \mathrm{kg}$ (Nursyamsi et al. 2008), whereas at ultisols lampung and oxisols sitiung for maize were 0.41 and $0.72 \mathrm{c} \mathrm{mol} \mathrm{kg}^{-1}$, respectively with neutral normal ammonium acetate (Sulaeman et al. 2000). However no such information is available for the crops and soils of PNG. Depletion of $\mathrm{K}$ under agricultural gardens could be due to mining of nutrients in crop produce and off take of nutrients. The results show an evidence for the lack of nutrient cycling in agricultural gardens compared secondary and plantation forests. Variations in concentration of $\mathrm{K}$ due to land use changes have been reported in ultisols of Peru and alfisols of Ghana (Sanchez 1976). Land use variations could be also due to the textural changes among different land uses. For example, the secondary forest land had greater amounts of silt $(p<0.05)$ and clay content than those under agricultural gardens. Available potassium content in soils depends on soil texture and types of soil minerals and is directly proportional to quantity of finer fractions viz., silt, and clay content (Nursyamsi et al. 2008).

Results in Table 3 shows that soil $\mathrm{pH}$ had a negative but significant relationship $(p<0.05)$ with SOC content $\left(r=-0.438^{*}\right)$, total $\mathrm{N}(r=0.422 *)$, and Bray's phosphorous contents $\left(r=-0.457^{*}\right)$. As the land use changed from secondary forest to other types, $\mathrm{pH}$ tended to increase, thus affecting other soil chemical properties. Such increase in $\mathrm{pH}$ specifically under grasslands and agricultural gardens could have increased organic matter decomposition in soil and hence promote greater mineralization and leaching losses of soluble $\mathrm{N}$ from the soil system.

\section{Conclusion}

Conversion of natural vegetation into other land covers considerably affects soil physical and chemical properties. Therefore land conversion to other uses must be managed carefully to retain soil fertility and continuous productivity. Conversion of natural forest land into agricultural and grassland is of particular risk; however, conversion of grasslands into agricultural gardens could improve soil physical and chemical properties due to increase of above ground biomass, traditional tillage, mineralization of plant residues, and nutrient input by legume plants from atmosphere. Furthermore, management strategies such as fallowing periods of slash and burn systems should be long enough to allow nutrient replenishment and stabilization of soil physical properties.

\section{Acknowledgements}

I would like to sincerely express my gratitude and appreciation for the funding support from UNITECH Scientific and Research Committee and NARI Headquarters for making funds available for laboratory analysis and compensate landowners during the survey.

\section{References}

ASTM. 2003. Standard test method for infiltration rate of soils in field using double-ring infiltrometer. In: Annual Book of ASTM Standards-Testing Materials. West Conshohocken, USA.

Batjes NH, Dijkshoorn JA. 1999. Carbon nitrogen stocks in the soil of Amazon Region. Geoderma 89: 273-286. http://dx.doi.org/10.1016/S0016-7061(98)00086-X.

Belton MC, O'Connor KF, Robson AB. 1996. Phosphorous levels in topsoils under Conifer plantations in Canterbury High Country grasslands. Research report No.96/04. New Zealand: Centre for computing and biometrics, Lincoln University.

Binkley D. 1986. Forest Nutrition Management. North Carolina: Duke University Press.

Blakemore LC, Searle PL, Daly BK. 1987. Methods for Chemical Analysis of Soils. New Zealand: New Zealand Soil Bureau Scientific Report 80.

Bray RH, Kurtz LT. 1945. Determination of total organic and available forms of phosphorus in soils. Soil Science 59:39-45. http://dx.doi.org/10.1097/00010694194501000-00006. 
Breget AK, Hartemink AE, Ningal T. 2008. Land cover and population growth in Morobe province, Papua New Guinea, between 1975 to 2000. Journal of Environmental Management 87:117-124. http://dx.doi.org/10.1016/j.jenvman.2007.01.006.

Bulluck LR III, Brosius M, Evanylo GK, Ristaino JB. 2002. Organic and synthetic fertility amendments influence soil microbial, physical and chemical properties in organic and conventional farms. Applied Soil Ecology 19:147-160. http://dx.doi.org/10.1016/S09291393(01)00187-1.

Deuchars SA, Townend J, Aitkenhead MJ, FitzPatrick EA. 1999. Changes in soil structure and hydraulic properties in regenerating rain forest. Soil Use and Management 15:183-187. http://dx.doi.org/10.1111/j.1475-2743. 1999.tb00086.x.

FAO. 1999. Prevention of land degradation, enhancement of carbon sequestration and conservation of biodiversity through land use change and sustainable land management with a focus on Latin America and the Caribbean. In: Proceedings of an IFAD/FAO Expert Consultation, Rome, Italy.

Gee GW, Bauder JW. 1986. Particle-size Analysis. In: Klute and Arnold (Editors). Methods of Soil Analysis Part 1, Physical and Mineralogical Methods. Madison: USA.

Gradwell MW, Birrell KS. 1979. Methods for physical analysis of soils. In: New Zealand Soil Bureau Scientific Report. Volume 10. New Zealand. pp. 10-29.

Handayani IP, Prawito P, Ihsan M. 2012. Soil changes associated with Imperata cylindrica grassland conversion in Indonesia. International Journal of Soil Science 7:61-70. http://dx.doi.org/10.3923/ijss. 2012.61.70.

Hanson LW, Allen BJ, Bourke RM, McCarthy TJ. 2001. Papua New Guinea Rural Development Handbook. Canberra: The Australian National University.

Hartemink AE, Veldkamp T, Bai Z. 2008. Land Cover Change and Soil Fertility Decline in Tropical Regions. ISRIC, Wageningen: World Soil Information.

Houghton RA. 1994. The worldwide extent of land-use change. Bioscience 44:305-313. http://dx.doi.org/10. $\underline{2307 / 1312380 .}$.

Humphreys G, Wayi B. 1990. Measuring soil erosion on steep lands: the Chimbu experience. In: Pushparajah E, Elliott CR, editors. Pacificland Workshop on the Establishment of Soil Management Experiments on Sloping Lands. Bangkok: International Boards of Soil Research and Management.

Jobbagy EG, Jackson RB. 2003. Patterns and mechanisms of soil acidification in the conversion of grasslands to forests. Biogeochemistry 64:205-229. http://dx.doi.org/10.1023/A:1024985629259.

Jordan CF. 1986. Amazonian Rain Forests, Ecosystem Disturbance and Recovery: Case Studies of Ecosystem Dynamics under a Spectrum of Land Use-Intensities. Athens: Institute of Ecology, University of Georgia.

Kizilkaya R, Denzig O. 2010. Variation of land use and land cover effects on some soil physico-chemical characteristics and soil enzyme activity. ZemdirbysteAgriculture 97:15-24.

Landon JR. 1991. Booker Tropical Soil Manual: A Handbook for Soil Survey and Agricultural Land Evaluation in the Tropics and Subtropics. New Jersey: Pearson Education.

Lichner L, Majercak J, Slabon S, Stekauerova V. 1994. Prenos Rozpustenych Latok $v$ Pode. Bratislava, Slovakia.

Cornelio DL, Killur RRB. 2011. Land use effects on soil erosion in the lowland humid tropics of Papua New Guinea. Jurnal Manajemen Hutan Tropika 17(1):1723.

McAlpine J, Freyne JD, Keig G. 2001. Land use and population change in PNG: 1975-1995. In: Bourke RM, Allen M, Salisbury J. (Editors). Food Security in Papua New Guinea. Canberra: ACIAR.

Neufeldt H, Resk DVS, Ayarza MA. 2002. Texture and landuse effects on soil organic matter in Cerrado Oxisols, Central Brazil. Geoderma 107:151-164. http://dx.doi.org/10.1016/S0016-7061(01)00145-8.

Nursyamsi D, Idris K, Sabiham S, Rachim DA, Sofyan A. 2008. Dominant soil characteristics influencing available potassium on smectitic soils. Indonesian Journal of Agriculture 1(2):121-131.

Oelmann Y, Richter AK, Roscher C, Rosenkranz S, Temperton VM, Weisser WW, Wilcke W. 2011. Does plant diversity influence phosphorus cycling in experimental grasslands? Geoderma 167:178-187.

Ogle SM, Breidt FJ, Eve MD, Paustian K. 2003. Uncertainty in estimating land use and management impacts on soil organic carbon storage for US agricultural lands between 1982 and 1997. Global Change Biology 9:1521-1542. http://dx.doi.org/10.1046/j.1365-2486. 2003.00683.x.

Sanchez PA. 1976. Properties and Management of Soils in the Tropics. New York: Wiley .

Schroth G, Sammya ADA, Teixeira WG, Haag D, Lieberei R. 2002. Conversion of secondary forest into agroforestry and monoculture plantation in Amazonia: consequences for biomass, litter and soil carbon stocks 
after 7 years. Forest Ecology and Management 163:131-150. http://dx.doi.org/10.1016/S0378$\underline{1127(01) 00537-0 .}$.

Shearman P, Ash J, Mackey B, Bryan JE, Lokes B. 2009. Forest Conversion and Degradation in Papua New Guinea between 1972-2002. Journal of Biotropica 41:379-390. http://dx.doi.org/10.1111/j.1744-7429. 2009.00495.x.

Shearman P, Ash J, Mackey B, Bryan JE, Lokes B. 2008. The state of the forests of Papua New Guinea. Mapping the extent and condition of forest cover and measuring the drivers of forest change in the period 1972-2002. Papua New Guinea:University of Papua New Guinea.

Sulaeman, Eviati S, Atikah, Adiningsih JS. 2000. Hubungan kuantitas dan intensitas kalium untuk menduga kemampuan tanah dalam persediaan hara kalium. In: Proceedings Seminar Nasional Reorientasi
Pendayagunaan Sumberdaya Tanah, Iklim, dan Pupuk. Cipayung-Bogor, 31 Oktober-2 November 2000. hlm. 125-140.

Ugolini FC, Dahlgren RA, Shoji S, Ito T. 1988. An example of andolization and podzolization as revealed by soil solution studies, southern Hakkoda, northeastern Japan. Soil Science 145: 111-125. http://dx.doi.org/10.1097/ 00010694-198802000-00005.

van Noordwijk M, Cerri CC, Woomer PL, Nugroho K, Bernoux M. 1997. Soil carbon dynamics in the humid tropical forest zone. Geoderma 79:187-225. http://dx.doi.org/10.1016/S0016-7061(97)00042-6.

Yao MK et al. 2010. Effect of land use types on soil organic carbon and nitrogen dynamics in Mid-West Côte d'Ivoire. European Journal of Scientific Research 40:211-222. 